\title{
The CanMEDS scholar: the neglected competency in tomorrow's doctors
}

This article was published in the following Dove Press journal:

Advances in Medical Education and Practice

13 October 2014

Number of times this article has been viewed

\section{Rele Ologunde' \\ Ivana Di Salvo 2,3 \\ Ankur Khajuria' \\ 'Imperial College School of Medicine, Imperial College London, London, UK; ${ }^{2}$ Faculty of Medicine and Surgery, University of Pavia, Pavia, Italy; ${ }^{3}$ International Federation of Medical Students' Associations, Ferney- Voltaire, France}

\section{Dear editor}

In 1996, the Royal College of Physicians and Surgeons of Canada proposed a competency-based framework describing the core competencies of specialist physicians, one of which was a scholar. ${ }^{1}$ The UK General Medical Council has since provided advice on developing teachers and trainers in undergraduate medical education. ${ }^{2}$ However, guidance about how to most effectively incorporate this advice into the medical curriculum remains unclear.

Everyone within medical education and academia has a role and responsibility to play in promoting a healthy and positive research culture that is conducive to the training of young scientists and doctors. ${ }^{3}$ It is imperative for students to learn how irresponsible research practice may hinder scientific progress ${ }^{4}$ or cause undue harm to society at large such as the well-publicized, and now disproved and discredited, case of a purported link between autism and the measles, mumps and rubella vaccine. ${ }^{5}$

Unfortunately, many universities do not sufficiently teach students how to become a good researcher, how to publish successfully, or how to conduct responsible research. A recent survey of a cohort of $515 \mathrm{UK}$ medical students found that only $22 \%$ of students had been taught how to write a paper and only $30 \%$ had been taught how to write an abstract. ${ }^{6}$ This study also identified that only $12 \%$ of students surveyed had any experience of applying for ethics committee approval for a research project, ${ }^{6}$ thus raising concerns about whether students are aware of the different types of research necessitating ethics approval and the types of research that do not require ethics approval.

The lack of training related to research methodologies and publications led the International Federation of Medical Students' Associations to organize its first preGeneral Assembly workshop during their meeting in Tunisia in March 2014, with the aim of providing insight into good research practice and dissemination of results. Moreover, in the last 20 years, with the advent of the Internet and the diffusion of accessible computing among the masses, we have witnessed a total revolution in the dissemination of information. The advantages of new technologies from social networking to artificial intelligence and from big data exchange to mobile processing are now everyday concepts that define the scientific landscape within which current medical students work. As such, it is vital that medical students continue to have the opportunity to develop scholarly principles early on in their careers, as this will promote a lifelong commitment to reflective learning and dissemination and application of evidence-based medicine. ${ }^{1}$
Correspondence: Rele Ologunde Imperial College School of Medicine, Imperial College London, Exhibition Road, London SW7 2AZ, UK

Email rele.ologunde09@imperial.ac.uk 


\section{Disclosure}

The authors have no conflicts of interest in this communication.

\section{References}

1. Cruess S, Johnston S, Cruess R. "Profession": a working definition for medical educators. Teach Learn Med. 2004;16(1):74-76.

2. General Medical Council. Developing Teachers and Trainers in Undergraduate Medical Education. Advice supplementary to Tomorrow's Doctors. London: General Medical Council; 2009. Available from: www. gmc-uk.org/Developing_teachers_web.pdf_40939758.pdf. Accessed October 2, 2014.
3. National Institute of Health - Office of Extramural Research. Research Integrity. Available from: http://grants.nih.gov/Grants/research_integrity/ done.htm. Accessed July 2, 2014.

4. Khajuria A, Agha R. Fraud in scientific research - birth of the Concordat to uphold research integrity in the United Kingdom. $J$ R Soc Med. 2014;107(2):61-65.

5. The Editors of the Lancet. Retraction - Ileal-lymphoid-nodular hyperplasia, non-specific colitis, and pervasive developmental disorder in children. Lancet. 2010;375(9713):445.

6. Griffin MF, Hindocha S. Publication practices of medical students at British medical schools: experience, attitudes and barriers to publish. Med Teach. 2011;33(1):e1-e8.

\section{Publish your work in this journal}

Advances in Medical Education and Practice is an international, peerreviewed, open access journal that aims to present and publish research on Medical Education covering medical, dental, nursing and allied health care professional education. The journal covers undergraduate education, postgraduate training and continuing medical education including emerging trends and innovative models linking education, research, and health care services. The manuscript management system is completely online and includes a very quick and fair peer-review system. Visit http://www.dovepress.com/testimonials.php to read real quotes from published authors.

Submit your manuscript here: http://www.dovepress.com/advances-in-medical-education-and-practice-journal 